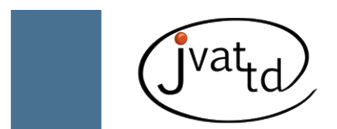

\title{
Euscorpius (Scorpiones, Euscorpiidae): three cases of stings in northwestern Italy
}

Dutto M (1), Dutto L (2), Scaglione N (2), Bertero M (3)

(1) Medical Entomology Collaborator, Santa Croce e Carle General Hospital, Cuneo, Italy; (2) Department of Emergency Medicine, Santa Croce e Carle General Hospital, Cuneo, Italy; (3) Department of Dermatology, Santa Croce e Carle General Hospital, Cuneo, Italy.

\begin{abstract}
In the period between June 2008 and August 2009, three cases of stings of Euscorpius scorpions indigenous to Italy were treated at two different emergency departments (ED) in hospitals of the Piedmont region, northwest Italy: Santa Croce e Carle General Hospital in Cuneo, and Santissima Annunziata Hospital in Savigliano. Scorpion stings in Italy are rare and not well documented in the literature; this situation may raise doubts among medical personnel as to how such lesions are best treated. Analysis of the incidents confirms that the venom of Euscorpius do not provokes systemic poisoning in humans and in these cases even dermatological reactions were not significant.
\end{abstract}

Key words: Euscorpius, scorpion, sting, scorpionism, venom, poisoning, Italy.

\section{INTRODUCTION}

Scorpions have always been a cause for alarm to the general population and, as such, are considered to be a dangerous species that may cause severe poisoning and even death. Italy has only a few indigenous scorpion species. Publications about Italian fauna continually confirm the presence of merely seven species, all belonging to the genus Euscorpius Thorell, 1876, which is relatively harmless to humans (1).

Scorpion species have a venom gland attached to the aculeus, which is located at the end of their "tail". The aculeus is used for scorpion self-defense, when the animal feels threatened or accidentally is accidentally provoked (2). Its venom varies from species to species and comprises a heterogeneous mixture of substances used primarily for capturing and killing prey. Several toxins are present, including those activated against insects, mammals and other homeothermic animals, and crustaceans $(3,4)$.
The neurotoxins found in scorpion venom that are harmful to humans affect mainly sodium channels in excitable cells (5).

In humans, toxic reactions to scorpion venoms depend on several factors, including: the scorpion species, toxin type, amount of toxin, and the age and physical condition of the victim. In general, venoms that are rich in neurotoxins cause the majority of the clinical problems and deaths; most of these occur in children, people with chronic pathologies, and the elderly $(6,7)$. Human reactions to scorpion stings are divided into three phases/grades of increasing severity, as shown in Table 1.

Scorpion stings account for a significant number of poisoning cases that occur annually throughout the globe (8). The most dangerous species to humans belong to the genera Leiurus, Androctonus, Buthus, Tityus, and Centruroides (Buthidae family) (7-9). Seven geographic areas are identified as most risky: North Africa, Sub-Saharan Africa, the Near East, the Middle 
Table 1. Severity and progression of poisoning caused by scorpion stings in increasing degrees of severity

\begin{tabular}{|c|c|c|}
\hline $\begin{array}{l}\text { Phase/ } \\
\text { grade }\end{array}$ & Clinical characteristics & Timeframe \\
\hline 1 & $\begin{array}{l}\text { - Local pain } \\
\text { - Swelling and redness at } \\
\text { the sting site } \\
\text { - Muscle spasms/cramps, } \\
\text { local paresthesia } \\
\text { - Slight fever, restlessness, } \\
\text { general malaise } \\
\text { - Nausea }\end{array}$ & $\begin{array}{l}0-2 \text { hours } \\
\text { after the } \\
\text { event }\end{array}$ \\
\hline 2 & $\begin{array}{l}\text { - Increasing intense local } \\
\text { pain } \\
\text { - Onset of muscarinica } \\
\text { syndrome } \\
\text { - Arterial hypotension } \\
\text { alternating with } \\
\text { hypertensive crisis } \\
\text { (systolic } 20-30 \mathrm{mmHg} \\
\text { above normal) }\end{array}$ & $\begin{array}{l}\text { More than } \\
2 \text { hours } \\
\text { after the } \\
\text { event }\end{array}$ \\
\hline 3 & $\begin{array}{l}\text { - Fever } \\
\text { - Cardiovascular collapse } \\
\text { - Pulmonary edema } \\
\text { - Bronchial spasms } \\
\text { - Altered heart rate } \\
\text { - Myocardial ischemia } \\
\text { - Respiratory insufficiency }\end{array}$ & $\begin{array}{l}\text { More than } \\
2-4 \text { hours } \\
\text { after the } \\
\text { event }\end{array}$ \\
\hline
\end{tabular}

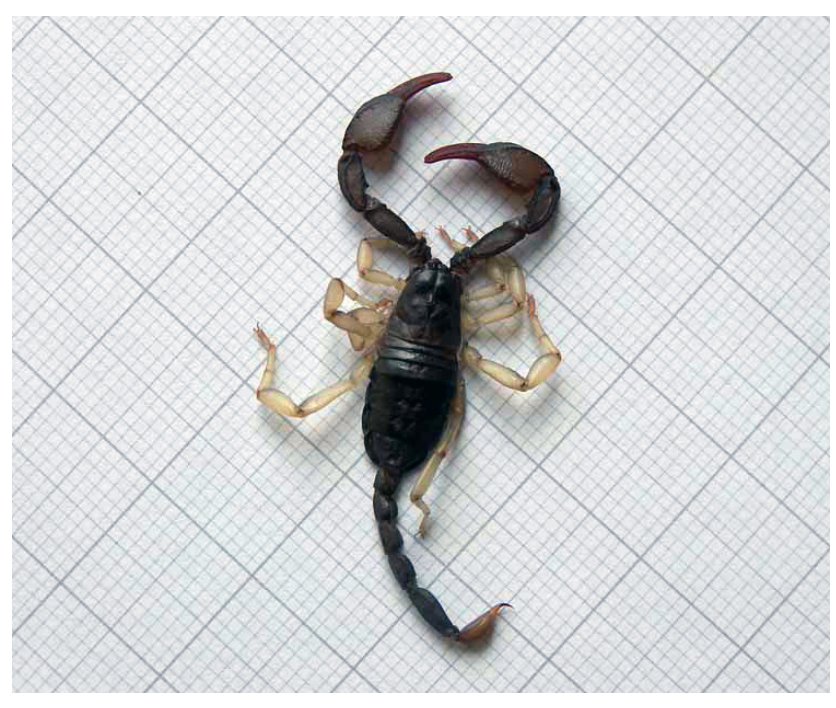

Figure 1. Adult specimen of Euscorpius species.

relatively small amount of the literature coupled with doctors' scarce entomological knowledge can leave the attending physician perplexed as to how to best proceed when confronted with such cases.

In order to better understand the clinical profile of Euscorpius stings we present herein three recent cases from northwest Italy.

\section{CASE REPORTS}

\section{Case 1}

In June 2008, a 27-year-old construction worker without any previous history of illness presented at the ED of the Santa Croce e Carle Hospital in Cuneo after having been stung on his left inner forearm near the elbow while putting on a sweater which had been left outdoors overnight at the worksite. He reported having seen a black scorpion measuring approximately 5 $\mathrm{cm}$. Prior to his arrival at the ED a tourniquet had been fashioned from a length of electrical wire. The patient's forearm bore a slightly swollen red lesion measuring around $20 \mathrm{~mm}$ with a darker red dot in the center indicating the point where the aculeus had penetrated. The victim complained of exhaustion, dizziness, headache and pain.

Upon arriving at the ED the patient received intravenous antihistamine (10 mg chlorphenamine) and underwent routine tests (vital signs, 12-lead ECG) that revealed no clinical abnormalities; body temperature was within normal limits. The patient confirmed that his tetanus coverage was up to date. Further 
tests included hourly readings of blood pressure, heart rate, oxygen saturation, body temperature and blood glucose over the next six hours. These precautionary measures were observed since concrete identification of the scorpion was not possible.

Approximately 40 minutes after arriving at the ED the pain and throbbing had subsided; the other symptoms had also diminished and the sting site was only visible as a slight cutaneous thickening.

However, one hour after being stung, the patient continued to complain of asthenia and general malaise, symptoms generally not attributed to Euscorpius sting, which was presumably the cause of the lesion. The incongruity between the patient's symptoms and the diagnosis, together with the presence of prick marks, perceived cigarette burns and signs of superficial thrombophlebitis on his arms resulted in suspicion of substance abuse. A toxicological urine test was performed and confirmed the presence of four illicit substances. At the end of the six-hour observation period the patient was discharged with no further therapy.

\section{Case 2}

In September 2008, a 47-year-old man whose medical history had no prior pathologies presented at the ED of the Santa Croce Hospital in Cuneo having been stung on his back by a scorpion 20 minutes earlier. The lesion occurred in the bathroom of the patient's home as he was putting on his bathrobe. The patient complained of a sharp burning pain at the sting site; the surrounding area developed an erythema of approximately $25 \mathrm{~mm}$ diameter. The patient had captured the scorpion and therefore it was possible to confirm it was a Euscorpius spp.

Approximately 15 minutes after the arrival at the ED the pain had disappeared and the patient had only local discomfort and burning; the swelling had been replaced by a slight and limited cutaneous thickening with a red point at the center where the aculeus had penetrated. The victim did not complain any further about symptoms nor was there any alteration in his vital signs.

Given the relative harmlessness of the species that had stung the patient, treatment was limited to disinfecting the lesion and administering a tetanus injection. An hour after his arrival at the ED the patient was discharged and advised to observe the area over the next few days for signs of infection.

\section{Case 3}

In August 2009, a 40-year-old woman of Moroccan origins presented at the ED of the civic hospital in Fossano after having been stung on the index finger of her left hand by a scorpion while cleaning her house. The patient was able to catch the specimen and brought it with her to the hospital where personnel began intravenous administration of $20 \mathrm{mg}$ of chlorpheniramine. The patient was then transferred by ambulance to the Santissima Annunziata Hospital in Savigliano for entomological consultation.

She arrived in Savigliano prostrate, approximately 45 minutes after having been stung. Although the pain had already diminished somewhat, she complained of tingling in her left arm. Due to linguistic difficulties, it was hard to obtain the patient's medical, but she was able to express that she had experienced acute pain at the moment of the sting and paresthesia extending up the length of her arm within the first 15 minutes following the event.

In the ED the scorpion was identified as Euscorpius spp.; upon examination of the affected area it was not possible to identify precisely where the aculeus had penetrated the skin. Given the unusual intensity of the patient's symptoms, she was submitted to an ECG that revealed no anomalies while her blood pressure, body temperature and blood glucose were monitored over the next 45 minutes. After an hour in the ED her clinical manifestations had receded and she received a tetanus injection. Given her clinical profile and the notable reduction of her symptoms in this period, it was concluded that she had not been significantly poisoned and she was discharged.

\section{DISCUSSION}

In Italy only scorpions from the indigenous genus Euscorpius proliferate in residences in the older areas of cities. Indeed, it is fairly unlikely that someone will be stung in more modern neighborhoods where the ideal living conditions for scorpions are less common (humidity, cracks in walls or floors to hide).

Symptoms from the Euscorpius sting are strictly local and rapidly dissipate (Table 1, grade 
1). Systematic disturbances (nausea, vomiting, excitability and prickling or tingling sensations) are rarely reported apart from symptoms manifested psychologically due to the patient's fear and agitation.

From a medical-toxicological point of view, a Euscorpius sting virtually never represents a medical emergency and simply requires disinfecting the concerned area, verification of the patient's most recent tetanus vaccine and, if absolutely necessary, treating the pain with an analgesic (17). Although initially acute, the pain experienced from a Euscorpius sting tends to rapidly diminish and usually disappears almost completely within an hour after the event.

However, when it is not possible to capture and identify the scorpion responsible for the sting, the patient's condition should not be underestimated. Such situation could be dangerous since species not native to Italy's fauna (allocton species) are sometimes introduced to urban centers through commerce or illegal breeders, as it has been shown in reports of poisonings throughout Europe. A retrospective study in Europe on poisonings provoked by bites and stings of exotic animals kept domestically revealed that no less than $27 \%$ were from spiders and scorpions (18).

These patients deserve special medical attention and should undergo a 12-lead ECG and monitoring of the heartbeat since the venom of exotic species may provoke irregularities (tachyarrythmia and sometimes bradyarrythmia) as well as ischemic complications. Further, in such cases blood tests can reveal leukocyte, hyperglycemia, and increased levels for myocardial and pancreatic necrosis (19).

In conclusion, in an event that the scorpion is identified as Euscorpius, the patient (lacking lesions and systemic symptoms) can be discharged after the normal procedure of antiseptic wash and prophylactic tetanus shot. However, in cases in which the scorpion that stung the victim was not captured for identification, prolonged observation (minimum six hours) is advised, during which vital signs (body temperature, cardiac activity, blood pressure) and pain should be monitored and blood tests administered for leukocytes and glucose. Increasing pain may be a manifestation of severe poisoning from a more dangerous scorpion species, or more intense poisoning since scorpions are able to control the quantity of toxin secreted.
Particular attention must be given to patients of pediatric age or with confirmed cardiocirculatory or respiratory pathologies who are stung by non-indigenous highly venomous species. In children, the amount of neurotoxic venom can have a greater effect because of lower body weight, so that progression from phase 1 to phase 3 can be rapid (5). Scorpion poisoning in the latter group may aggravate their syndromes.

As for treatment, concerning an exotic species, at present there are no established guidelines and there is much discussion over whether specific or polyvalent antivenom is the best approach $(12,20,21)$. Stings of exotic species require the input and support from a medical entomologist. Medical personnel must be able to readily recognize the signs and symptoms that may appear following the sting from allocton species, thereby avoiding discharging patients prematurely and beginning, when necessary, the correct therapy (22) (Table 1).

\section{COPYRIGHT \\ (C) CEVAP 2010}

\section{SUBMISSION STATUS}

Received: May 21, 2010.

Accepted: July 1, 2010.

Abstract published online: August 13, 2010.

Full paper published online: November 30, 2010.

\section{CONFLICTS OF INTEREST}

There is no conflict.

\section{CORRESPONDENCE TO}

MORENO DUTTO, Dipartimento di

Prevenzione, Servizio di Igiene e Sanità Pubblica, Via del Follone, Saluzzo, Italia. Phone: +39 0175215613. Email: dutto.moreno@tiscali.it.

\section{REFERENCES}

1. Vignoli V, Crucitti P. Aggiornamenti alla Checklist delle specie della Fauna italiana. IX Contributo. Fascicolo 21: Arachnida Scorpiones, Palpigradi, Solifugae, Opiliones. Boll Soc Entomol Ital. 2003;134(3):279-81.

2. Yigit N, Benli M. The venom gland of the scorpion species Euscorpius mingrelicus (Scorpiones: Euscorpiidae): morphological and ultrastructural characterization. J Venom Anim Toxins incl Trop Dis. 2008;14(3):466-80.

3. Goyffon M, Chippaux JP. Animaux venimeux terrestres. Encyclopédie Médico-Chirurgicale, 
Intoxication, Pathologie du travail. Paris: Editions Techniques; 1990. p. 1-14.

4. Stockmann R, Goyffon M. Les scorpions. In: Goyffon M, Heurtault J, editors. La fonction venimeuse. Paris: Masson; 1995. p. 88-100.

5. Goyffon M, Billiald P. Envenimations VI. Le scorpionisme en Afrique. Med Trop. 2007;67(5):439-46.

6. Karalliedde L. Animal toxins. Br J Anaesth. 1995;74(1):319-27.

7. Joe G. Scorpioni. In: Olson KR, editor. Intossicazioni acute. Veleni, farmaci e droghe. Milano: Springer; 1999. p. 298-9.

8. Yigit $N$, Benli $M$. Fine structural analysis of the stinger in venom apparatus of the scorpion Euscorpius mingrelicus (Scorpiones: Euscorpiidae). J Venom Anim Toxins incl Trop Dis. $2010 ; 16$ (1):76-86.

9. Goyffon M. Le scorpionisme en Afrique subsaharienne. Bull Soc Path Exot. 2002;95(3):191-3.

10. Lourenco WR, Cuellar O. Scorpions, scorpionism, life history strategies and parthenogenesis. J Venom Anim Toxins. 1995;1(2):51-62.

11. Chippaux JP, Goyffon M. Envenomations et intoxication par les animaux venimeux ou vénéneux. I Généralites. Med Trop. 2006;66(3):215-20.

12. Chippaux JP, Goyffon M. Epidemiology of scorpionism: a global appraisal. Acta Tropica. 2008; 107(2):71-9.

13. Soulaymani Bencheikh R, Idrissi $M$, Tamin O, Semlali I, Mokhtari A, Tayebi M, et al. Scorpion stings in one province of Morocco: epidemiological, clinical and prognosis aspects. J Venom Anim Toxins incl Trop Dis. 2007;13(2):462-71.

14. Pastrana J, Blasco R, Erce R, Pinillos MA. Picaduras y mordeduras de animales. Anales Sis San Navarra. 2003;26(Suppl 1):225-41.
15. Torregiani F, La Cavera C. Puntura di scorpione (Euscorpius sp.) in Italia e rassegna dello scorpionismo. Minerva Med. 1990;81(Suppl 2):137-45.

16. De Haro L, Pommier P. Envenomation: a real risk of keeping exotic house pets. Vet Hum Toxicol. 2003;45(4):214-6.

17. Piolatto A. Urgenze da morsi e punture di animali. In: Garetto G, editor. La nuova medicina d'urgenza. Torino: C.G. Edizioni MedicoScientifiche; 1994. p. 1749-61.

18. Schaper A, Desel H, Ebbecke M, De Haro L, Deters $\mathrm{M}$, Hentschel $\mathrm{H}$, et al. Bites and stings by exotic pets in Europe: an 11 year analysis of 404 cases from Northeastern Germany and Southeastern France. Clin Toxicol (Phila). 2009;47(1):39-43.

19. Amitay Y. Clinical manifestations and management of scorpion envenomation. Public Health Rev. 1998;26(3):257-63

20. Ozkan O, Adiguzel S, Kar S, Yakistiran S, Cesaretli Y, Karaer KZ. Determination of potency and paraspecific effects of Androctonus crassicauda (Olivier, 1807) antivenom against Mesobuthus gibbosus (Brullé, 1832) venom (Scorpiones: Buthidae). J Venom Anim Toxins incl Trop Dis. 2007; 13(2):500-8.

21. Ozkan O, Adiguzel S, Inceoglu B, Lango J, Ertek $\mathrm{M}$, Hammock BD. Evaluation of the neutralizing capacity of Androctonus crassicauda (Olivier, 1807) antivenom against Leiurus quinquestriatus (Ebrenberg, 1928) venom (Scorpiones: Buthidae). J Venom Toxins incl Trop Dis. 2008;14(3):481-96.

22. Holve S. Treatment of snake, insect, scorpion and spider bites in the pediatric emergency department. Curr Opin Pediatr. 1996;8(3):25660. 